Zeszyty Naukowe Szkoły Głównej Gospodarstwa Wiejskiego

Ekonomika i Organizacja Gospodarki Żywnościowej nr 115, 2016: 91-99

Dorota Komorowska

Katedra Ekonomiki Rolnictwa i Międzynarodowych Stosunków Gospodarczych

Szkoła Główna Gospodarstwa Wiejskiego w Warszawie

\title{
Efektywność ekologicznych gospodarstw sadowniczych w porównaniu do konwencjonalnych
}

\section{Wstęp}

Rozwój produkcji rolniczej uzyskiwanej metodami ekologicznymi jest warunkowany zapotrzebowaniem na produkty oraz efektywnością ekonomiczną jej wytwarzania. Notowane od lat 80. ubiegłego wieku zagrożenia związane z bezpieczeństwem żywności o zasięgu międzynarodowym spowodowały, że konsumenci (także w Polsce) zwracają coraz większą uwagę na tą kwestię. Największe obawy w kontekście bezpieczeństwa żywności budzi sposób produkcji i przetwarzania żywności oraz stopień ingerencji w te procesy. W związku z tym żywność ekologiczna i tradycyjna jest oceniana jako niosąca najmniejsze zagrożenie [Tyburski i in. 2007, Żakowska-Biemans 2011]. Żywność ekologiczna jest postrzegana jako „naturalna”, tradycyjna natomiast jest łączona z tradycyjnym sposobem produkcji i przetwarzania, co budzi zaufanie konsumentów i przekłada się na ich zachowania rynkowe. $Z$ tego powodu obserwuje się systematyczny wzrost popytu na produkty ekologiczne i tradycyjne oraz rozwój rynków tego typu produktów.

Wzrost popytu na produkty ekologiczne stwarza możliwości rozwoju produkcji ekologicznej, w tym owoców i warzyw, które należą do produktów najchętniej kupowanych na ekologicznym rynku żywnościowym [Willer i in. 2013]. $\mathrm{Z}$ danych statystycznych dotyczących rolnictwa ekologicznego na świecie wynika, że Polska jest krajem o największej powierzchni ekologicznych plantacji drzew i krzewów owocowych do produkcji owoców strefy umiarkowanej (jabłonie, grusze, śliwy, czereśnie, wiśnie, brzoskwinie, morele, maliny, porzeczki) zarówno w Europie, jak i na świecie [The World of Organic Agriculture ... 2015]. Powierzchnia ekologicznych plantacji drzew i krzewów owocowych w Polsce 
w 2012 roku została wyszacowana na 42 tys. ha i stanowiła $35 \%$ powierzchni ekologicznych plantacji drzew i krzewów owocowych w Europie oraz 27\% powierzchni ekologicznych plantacji drzew i krzewów owocowych na świecie. Wynika to z dużego udziału ekologicznych plantacji jabłoni, których powierzchnia w naszym kraju stanowi prawie połowę powierzchni ekologicznych plantacji jabłoni na świecie. W Polsce są także największe powierzchnie ekologicznych plantacji krzewów owocowych, w tym malin i czarnych porzeczek [Komorowska 2014].

Największy udział powierzchni ekologicznych plantacji sadowniczych w całkowitej powierzchni plantacji sadowniczych mają Czechy (w $2012 \mathrm{r}$. wyniósł on $34,1 \%$ ). Polska pod tym względem zajmuje drugą pozycję (odpowiednio $15,6 \%$ ) i wyprzedza pozostałe kraje o znaczącym udziale powierzchni ekologicznych sadów w całkowitej powierzchni sadów, czyli Niemcy $(14,4 \%)$, Łotwę (14,3\%), Finlandię (12,6\%) oraz Estonię (12,5\%). W związku z powyższym zainteresowanie wzbudzają wyniki produkcyjne i ekonomiczne naszych gospodarstw ekologicznych zajmujących się produkcją sadowniczą.

Z wieloletnich badań prowadzonych w IUNG-PIB w Puławach nad integrowanym, ekologicznym i konwencjonalnym systemem gospodarowania w rolnictwie wynika, że umiarkowana specjalizacja, czyli roślinny lub zwierzęcy kierunek produkcji w gospodarstwie zwiększa efektywność gospodarstw ekologicznych [Kuś i in. 2005, Stalenga 2010]. W obrębie ogółu gospodarstw ekologicznych można wyodrębnić gospodarstwa o określonym typie produkcyjnym ${ }^{1}$, $\mathrm{w}$ tym nastawione na uprawy sadownicze [Nachtman 2010]. W związku z tym, że Polska jest krajem o znaczącej powierzchni ekologicznych plantacji drzew i krzewów owocowych to sadownicze gospodarstwa ekologiczne i konwencjonalne są przedmiotem analizy porównawczej.

\section{Cel i metodyka badań}

Celem opracowania jest ocena efektywności gospodarowania zasobami produkcyjnymi w sadowniczych gospodarstwach ekologicznych w porównaniu do konwencjonalnych, objętych rachunkowością rolną w systemie FADN ${ }^{2}$ w 2013 roku. W badanym roku w próbie Polskiego FADN było 17 gospodarstw ekologicznych i 439 gospodarstw konwencjonalnych nastawionych na uprawy sadownicze.

\footnotetext{
${ }^{1}$ Typ produkcyjny gospodarstwa rolnego określany jest udziałem wartości produkcji z poszczególnych działalności rolniczych w wartości produkcji całkowitej gospodarstwa.

${ }^{2}$ FADN to jednolity system zbierania danych rachunkowych we wszystkich krajach członkowskich UE, służący m.in. do kreowania wspólnej polityki rolnej. W Polsce od 2004 roku IERiGŻ-PIB prowadzi badania rachunkowości rolnej w systemie FADN, określanym jako Polski FADN.
} 
Zaprezentowane $\mathrm{w}$ opracowaniu wyniki są średnimi dla porównywanych grup gospodarstw, a zgodnie z założeniami obowiązującego systemu rachunkowości rolnej badaniem były objęte tylko gospodarstwa towarowe [Goraj i Mańko 2009].

Efektywność gospodarowania zasobami produkcyjnymi w gospodarstwach rolnych mierzy się, odnosząc ujęcie wartościowe efektów produkcyjnych oraz wyniki ekonomiczne gospodarstw do wkładu czynników wytwórczych zaangażowanych w ich uzyskanie. Odniesienie odpowiednio wyników produkcyjnych pozwala ustalić efektywność produkcyjną, a wyników ekonomicznych - efektywność ekonomiczna. Odniesienie wartości uzyskanej produkcji do wielkości zasobów ziemi użytkowanych w badanych gospodarstwach pozwoliło ustalić produktywność zasobów ziemi. Odniesienie wartości produkcji do wielkości wkładu pracy w jej wytworzenie (wkładu pracy przeliczonego na pełny wymiar czasu pracy) pozwoliło obliczyć produktywność wydatkowanej pracy (ekonomiczną wydajność pracy). Przeliczenie wartość uzyskanej produkcji na 100 zł wartości zaangażowanego kapitału w procesy wytwarzania porównywanych gospodarstw pozwoliło ustalić produktywność kapitału przypadającą na jednostkę jego wartości. Z kolei odniesienie odpowiednio wyniku ekonomicznego (dochodu z gospodarstwa rolnego) do wkładu zasobów produkcyjnych zaangażowanych w jego wypracowanie pozwoliło ocenić efektywność ekonomiczną gospodarowania zasobami w badanych gospodarstwach sadowniczych (dochodowość zasobów ziemi, wydatkowanej pracy i zaangażowanego kapitału).

\section{Potencjał produkcyjny badanych gospodarstw}

Przeciętna powierzchnia użytków rolnych (UR) badanych gospodarstw sadowniczych była wyraźnie zróżnicowana. Gospodarstwa ekologiczne gospodarowały prawie dwukrotnie większą powierzchnią UR niż konwencjonalne. Przeciętna powierzchnia UR gospodarstw ekologicznych wynosiła 18 ha, a konwencjonalnych - 9,6 ha (tab. 1). Zarówno gospodarstwa ekologiczne, jak i konwencjonalne gospodarowały głównie własnymi gruntami (dzierżawienie użytków rolnych miało niewielkie znaczenie). Przeważającą część powierzchni UR w obu grupach gospodarstw zajmowały plantacje sadownicze (ponad 80\%).

Na podstawie danych rachunkowości rolnej FADN z zakresu zasobów pracy gospodarstw rolnych można podać tylko wkład zasobów pracy w procesy produkcyjne gospodarstw, czyli nakłady pracy. Z tych danych wynika, że roczne nakłady pracy ogółem $w$ przeliczeniu na pełnozatrudnionego w ciagu roku $\left(\mathrm{wAWU}^{3}\right) \mathrm{w}$ badanych gospodarstwach sadowniczych kształtowały się na zbliżonym poziomie.

\footnotetext{
${ }^{3} \mathrm{AWU}$ - jednostka przeliczeniowa nakładów pracy według metodyki FADN: 1 jednostka AWU $=2200$ godzin pracy ogółem/rok. W nakładach pracy ogółem ujmuje się nakłady pracy własnej rolnika i jego rodziny oraz nakłady pracy najemnej.
} 
Tabela 1

Zasoby produkcyjne badanych gospodarstw

\begin{tabular}{|l|c|c|}
\hline \multirow{2}{*}{ Wyszczególnienie } & \multicolumn{2}{|c|}{ Gospodarstwa } \\
\cline { 2 - 3 } & ekologiczne & konwencjonalne \\
\hline Średnia powierzchnia użytków rolnych [ha] & 18,0 & 9,6 \\
w tym dzierżawionych [ha] & 0,5 & 0,9 \\
Powierzchnia plantacji sadowniczych [ha] & 15,6 & 7,7 \\
Udział plantacji sadowniczych w powierzchni & & \\
użytków rolnych [\%] & 86,7 & 80,2 \\
Nakłady pracy ogółem [AWU] & 2,25 & 2,24 \\
Aktywa ogółem [zł] & 850769 & 704199 \\
\hline
\end{tabular}

Źródło: Obliczenia własne na podstawie danych IERiGŻ-PIB.

Potencjał zasobów kapitałowych gospodarstw rolnych stanowią środki produkcyjne trwałe i obrotowe, których wartość obrazują aktywa ogółem. Zasoby kapitałowe badanych gospodarstw sadowniczych stanowiły w głównej mierze środki trwałe, w tym uprawy trwałe (sady), ale także budynki, maszyny i urządzenia. Ich wartość była większa o około $20 \%$ w gospodarstwach ekologicznych, ale gospodarstwa ekologiczne były prawie dwukrotnie większe od konwencjonalnych.

\section{Wyniki produkcyjne i produktywność czynników wytwórczych}

Wartość produkcji ogółem ${ }^{4} \mathrm{w}$ badanych gospodarstwach sadowniczych kształtowała przede wszystkim produkcja owoców (tab. 2). W gospodarstwach ekologicznych wartość produkcji owoców stanowiła $96 \%$ wartości produkcji ogółem, w konwencjonalnych - 92\%. Zatem niewielki udział w wynikach produkcyjnych tych gospodarstw miała pozostała produkcja roślinna i produkcja zwierzęca. W zakresie produkcji roślinnej badane gospodarstwa sadownicze prowadziły także uprawę zbóż, roślin oleistych, ziemniaków i roślin pastewnych, ale wartość tej produkcji stanowiła tylko 1,5\% wartości produkcji ogółem gospodarstw ekologicznych i 2,4\% wartości produkcji ogółem gospodarstw konwencjonalnych. W zakresie produkcji zwierzęcej analizowane gospodarstwa prowadziły na niewielką skalę chów bydła, trzody chlewnej i drobiu, dlatego udział wartości produkcji zwierzęcej w wartości produkcji ogółem tych gospodarstw był znikomy.

\footnotetext{
${ }^{4}$ Zgodnie z metodyką FADN wyniki produkcyjne gospodarstw stanowi produkcja ogółem, która ujmuje produkcję rolniczą roślinną i zwierzęcą oraz pozostałą produkcję, a także przychody, np. z dzierżawienia ziemi, wynajmu budynków, maszyn, świadczenia usług.
} 
W związku z tym, że gospodarstwa ekologiczne w porównaniu do konwencjonalnych były prawie dwukrotnie większe obszarowo i prowadziły produkcję sadowniczą na większą skalę (tab. 1) to zarazem ich wyniki produkcyjne ukształtowały się na wyższym poziomie (tab. 2).

\section{Tabela 2}

Wartość produkcji badanych gospodarstw [zł]

\begin{tabular}{|l|c|c|}
\hline \multirow{2}{*}{ Wyszczególnienie } & \multicolumn{2}{|c|}{ Gospodarstwa } \\
\cline { 2 - 3 } & ekologiczne & konwencjonalne \\
\hline Produkcja ogółem & 159479 & 119851 \\
Produkcja roślinna w tym: & 157297 & 118151 \\
zboża & 900 & 1983 \\
nasiona roślin białkowych & 561 & 280 \\
ziemniaki & 259 & 315 \\
owoce & 153524 & 109923 \\
Produkcja zwierzęca w tym: & 182 & 226 \\
mleko & 128 & 31 \\
żywiec wołowy & 39 & 24 \\
żywiec wieprzowy & 0 & 77 \\
\hline
\end{tabular}

Źródło: Jak w tabeli 1.

Odniesienie wyników produkcyjnych badanych gospodarstw do wkładu czynników wytwórczych zaangażowanych w ich uzyskanie pozwoliło obliczyć produktywność zasobów porównywanych gospodarstw (tab. 3). Produktywność zasobów ziemi gospodarstw ekologicznych była mniejsza niż konwencjonalnych, co wynikało z mniejszej wydajności ich ekologicznych metod wytwarzania. Ekonomiczna wydajność pracy ukształtowała się na wyższym poziomie w gospodarstwach ekologicznych, ponieważ były one znacznie większe od konwencjonalnych. Z kolei produktywność zasobów kapitałowych analizowanych gospodarstw nie różniła się znacząco, można nawet uznać, że ukształtowała się na zbliżonym poziomie w obu grupach gospodarstw.

Poziom wskaźników produktywności czynników wytwórczych porównywanych gospodarstw odzwierciedlał ich skalę produkcji oraz poziom wyników produkcyjnych uzyskanych w badanym roku.

\section{Tabela 3}

Produktywność zasobów produkcyjnych badanych gospodarstw

\begin{tabular}{|l|c|c|}
\hline \multirow{2}{*}{ Wyszczególnienie } & \multicolumn{2}{|c|}{ Gospodarstwa } \\
\cline { 2 - 3 } & ekologiczne & konwencjonalne \\
\hline Produktywność ziemi [zł/ha] & 8860 & 12484 \\
Ekonomiczna wydajność pracy [zł/AWU] & 70880 & 53505 \\
Produktywność na 100 zł aktywów ogółem [zł] & 18,75 & 17,02 \\
\hline
\end{tabular}

Źródło: Jak w tabeli 1. 


\section{Wyniki ekonomiczne i dochodowość czynników wytwórczych}

Dochód z rodzinnego gospodarstwa rolnego ${ }^{5}$ stanowi opłatę zaangażowania czynników wytwórczych gospodarstw rolnych w procesy produkcji rolniczej. Syntetyczny rachunek wyników ekonomicznych badanych gospodarstw sadowniczych przedstawiono w tabeli 4 . Wyniki produkcyjne gospodarstw ekologicznych ukształtowały się na wyższym poziomie, ale koszty produkcji w tych gospodarstwach były mniejsze. Koszty materiałowe gospodarstw ekologicznych ukształtowały się na o połowę niższym poziomie niż konwencjonalnych, co wynikało ze znacznie mniejszych kosztów nawożenia i ochrony roślin oraz nasion i sadzonek. Koszty amortyzacji środków trwałych były mniejsze w gospodarstwach ekologicznych, ponadto mniejsze w nich były także koszty zewnętrznych czynników produkcji (wynagrodzenia pracowników najemnych, czynsze dzierżawne, odsetki od kredytów). Wyższy poziom wyników produkcyjnych przy mniejszych kosztach produkcji gospodarstw ekologicznych uwarunkował trzykrotnie większe dochody w tychże gospodarstwach. Przyczyniły się do tego wyższe ceny ekologicznych produktów roślinnych, w tym głównie owoców oraz mniejsze koszty ekologicznego wytwarzania.

\section{Tabela 4}

Rachunek wyników porównywanych gospodarstw [zł]

\begin{tabular}{|l|c|c|}
\hline \multirow{2}{*}{ Wyszczególnienie } & \multicolumn{2}{|c|}{ Gospodarstwa } \\
\cline { 2 - 3 } & ekologiczne & konwencjonalne \\
\hline Produkcja ogółem & 159479 & 119851 \\
Koszty materiałowe & 20022 & 42452 \\
Koszty amortyzacji & 21593 & 31016 \\
Koszty zewnętrznych czynników produkcji & 12648 & 16440 \\
Podatki, opłaty & 1815 & 1013 \\
Saldo podatku VAT & 5689 & 45 \\
Dochód z gospodarstwa rolnego bez dopłat & 109090 & 28975 \\
Dopłaty & 38522 & 14029 \\
Dochód z gospodarstwa rolnego z dopłatami & 147612 & 43004 \\
\hline
\end{tabular}

Źródło: Jak w tabeli 1.

\footnotetext{
${ }^{5}$ „Dochód z rodzinnego gospodarstwa rolnego" to kategoria dochodowa według metodyki FADN, określana w niniejszym opracowaniu w skrócie jako „dochód z gospodarstwa rolnego". Odpowiada dochodowi rolniczemu netto z uwzględnieniem dopłat do działalności gospodarstw rolnych. $\mathrm{W}$ celu określenia udziału dopłat $\mathrm{w}$ dochodzie badanych gospodarstw oraz oceny efektywności gospodarowania zasobami obliczono „,dochód z gospodarstwa rolnego bez dopłat” oraz „dochód z gospodarstwa rolnego z dopłatami”.
} 
Wpływ polityki rolnej na wyniki ekonomiczne gospodarstw rolnych przejawia się $\mathrm{w}$ realizowanych dopłatach do ich działalności. Według metodyki FADN dopłaty do działalności produkcyjnej oraz inwestycyjnej gospodarstw sa ujmowane przy obliczaniu dochodu z gospodarstwa rolnego. Dopłaty do działalności produkcyjnej gospodarstw ekologicznych obejmują jednolitą płatność obszarową oraz dopłaty do ekologicznych upraw polowych, upraw trwałych, ogrodniczych i trwałych użytków zielonych. W badanych gospodarstwach sadowniczych poziom dopłat do ich działalności był większy w gospodarstwach ekologicznych, co wynikało z większej skali produkcji oraz wyższego poziomu dopłat do działalności produkcyjnej gospodarstw ekologicznych. W końcowym efekcie dopłaty podwyższyły bardziej dochody gospodarstw ekologicznych niż konwencjonalnych, ale udział dopłat $\mathrm{w}$ dochodzie $\mathrm{z}$ gospodarstwa rolnego był większy w gospodarstwach konwencjonalnych $(32,6 \% \mathrm{w}$ konwencjonalnych, $26,1 \%$ w ekologicznych).

Efektywność ekonomiczną gospodarowania zasobami w badanych gospodarstwach sadowniczych, czyli dochodowość zasobów ziemi, wydatkowanej pracy i zaangażowanego kapitału w procesy wytwarzania porównywanych gospodarstw, przedstawiono w tabeli 5. Dochodowość zasobów ziemi gospodarstw ekologicznych była dwukrotnie większa niż konwencjonalnych, co wynikało głównie z wyższego poziomu wyników produkcyjnych przy mniejszych kosztach produkcji gospodarstw ekologicznych. Dochodowość wydatkowanej pracy i zaangażowanego kapitału ukształtowała się nawet na kilkukrotnie wyższym poziomie w gospodarstwach ekologicznych, ponieważ były one przede wszystkim większe od konwencjonalnych i osiągnęły znacznie lepsze wyniki ekonomiczne niż gospodarstwa konwencjonalne.

\section{Tabela 5}

Dochodowość zasobów produkcyjnych badanych gospodarstw

\begin{tabular}{|l|c|c|}
\hline \multirow{2}{*}{ Wyszczególnienie } & \multicolumn{2}{|c|}{ Gospodarstwa } \\
\cline { 2 - 3 } & ekologiczne & konwencjonalne \\
\hline Dochód z gospodarstwa rolnego na 1 ha UR & & \\
[zł/ha] & 6061 & 3018 \\
Dochodowość pracy własnej [zł/osobe] & 75968 & 20178 \\
Dochodowość aktywów ogółem [\%] & 12,8 & 4,2 \\
\hline
\end{tabular}

Źródło: Jak w tabeli 1.

\section{Podsumowanie}

Badane gospodarstwa ekologiczne i konwencjonalne były zróżnicowane w zakresie wielkości obszarowej i skali produkcji sadowniczej. Gospodarstwa ekologiczne gospodarowały prawie dwukrotnie większą powierzchnią UR niż 
konwencjonalne, dlatego ich plantacje sadownicze były dwukrotnie większe. Gospodarstwa ekologiczne uzyskały wyższy poziom wyników produkcyjnych, ale produktywność ich zasobów ziemi była mniejsza niż konwencjonalnych, co wynikało z mniejszej wydajności ekologicznych metod wytwarzania. Produktywność zasobów kapitałowych ukształtowała się na zbliżonym poziomie w obu grupach gospodarstw, ekonomiczna wydajność pracy była natomiast większa w gospodarstwach ekologicznych, ponieważ były one większe od konwencjonalnych.

Gospodarstwa ekologiczne uzyskały także wyższy poziom wyników ekonomicznych niż konwencjonalne, co warunkowały lepsze wyniki produkcyjne przy mniejszych kosztach produkcji. Przyczyniły się do tego wyższe ceny sprzedaży owoców ekologicznych oraz mniejsze koszty ekologicznego wytwarzania. W efekcie dochodowość zasobów ziemi, wydatkowanej pracy i zaangażowanego kapitału w procesy produkcyjne badanych gospodarstw sadowniczych była większa w przypadku gospodarstw ekologicznych.

\section{Literatura}

GORAJ L., MAŃKO S., 2009: Rachunkowość i analiza ekonomiczna w indywidualnym gospodarstwie rolnym, Centrum Doradztwa i Informacji Difin, Warszawa.

KOMOROWSKA D., 2014: Rozwój produkcji ekologicznej i rynku żywności ekologicznej na świecie, Roczniki Naukowe SERiA 16 (6), 254-262.

KUŚ J., KOPIŃSKI J., MADEJ A., STALENGA J., 2005: Kompleksowa ocena gospodarstw ekologicznych w rejonie Brodnicy (woj. kujawsko-pomorskie), [w:] Kompleksowa ocena gospodarstw ekologicznych oraz wybrane aspekty funkcjonowania rynku żywności ekologicznej, Raport naukowy, IUNG Puławy, s. 26-39.

NACHTMAN G., 2010: Dochodowość i opłacalność produkcji w gospodarstwach ekologicznych specjalizujacych się $w$ uprawach polowych na podstawie danych Polskiego FADN, [w:] A. Harasim (red.), Stan obecny i perspektywy rozwoju rolnictwa ekologicznego $w$ Polsce, Studia i Raporty IUNG-PIB 26, 63-79.

STALENGA J., 2010: Efektywność ekonomiczna gospodarstw ekologicznych w rejonie Brodnicy, [w:] A. Harasim (red.), Stan obecny i perspektywy rozwoju rolnictwa ekologicznego w Polsce, Studia i Raporty IUNG-PIB 26, 37-50.

TYBURSKI J., ŻAKOWSKA-BIEMANS S., 2007: Wprowadzenie do rolnictwa ekologicznego, Wydawnictwo SGGW, Warszawa.

WILLER H., LERNOUD J., SCHAACK D., 2013: The European Market for Organic Food 2011, Research Institute of Organic Agriculture (FiBL), Frick, Switzerland i Foundation Ecology and Agricultural Informatio Company (AMI), Bonn, Germany.

The World of Organic Agriculture - Statistics and Emerging Trends, Research Institute of Organic Agriculture (FiBL), Frick, Switzerland i International Federation of Organic Agriculture Movements (IFOAM), Bonn, Germany 2015. 
ŻAKOWSKA-BIEMANS S., 2011: Bezpieczeństwo żywności jako czynnik determinujacy zachowania konsumentów na rynku żywności, Problemy Higieny i Epidemiologii 92 (3), 621-624.

\begin{abstract}
Abstrakt
Celem opracowania jest ocena efektywności gospodarowania zasobami produkcyjnymi $\mathrm{w}$ sadowniczych gospodarstwach ekologicznych na tle konwencjonalnych. Zaprezentowane $\mathrm{w}$ opracowaniu wyniki badanych gospodarstw wskazują na niższy poziom produktywności zasobów ziemi w gospodarstwach ekologicznych, co wynikało z mniejszej wydajności produkcji ekologicznej. Produktywność zasobów kapitałowych ukształtowała się na zbliżonym poziomie w obu grupach gospodarstw, ekonomiczna wydajność pracy była natomiast większa w gospodarstwach ekologicznych, ponieważ były one większe od konwencjonalnych. Gospodarstwa ekologiczne uzyskały wyższy poziom wyników ekonomicznych niż konwencjonalne, co warunkowały lepsze wyniki produkcyjne przy małych kosztach produkcji gospodarstw ekologicznych. $Z$ tego powodu dochodowość zasobów ziemi, wydatkowanej pracy i zaangażowanego kapitału w procesy produkcyjne badanych gospodarstw sadowniczych była większa w gospodarstwach ekologicznych.
\end{abstract}

Słowa kluczowe: rolnictwo ekologiczne, efektywność gospodarstw rolnych

\title{
Efficiency of organic and conventional fruit farms
}

\section{Abstract}

The aim of the study is to evaluate the efficiency of production factors in organic and conventional fruit farms. The results suggest lower level of productivity of land resources on organic farms, which resulted from lower productivity of organic production. The productivity of capital presented similar levels in both groups of households, while the productivity of the labor force was greater in organic farms, because they were bigger than conventional ones. Organic farms were characterised by better economic results than conventional ones, as a result of better production results accompanied by lower production costs of organic farms. Therefore, in the surveyed households, the profitability of land, labor and capital used in the production processes was higher in organic farms.

Key words: organic farming, efficiency of farms 